\title{
Morita-Baylis-Hillman Adducts Display Anti-Inflammatory Effects by Modulating Inflammatory Mediator Expression in RAW264.7 Cells
}

\author{
Glaucia V. Faheina-Martins, ${ }^{1}$ Jacqueline Alves Leite, ${ }^{2}$ Bruna Braga Dantas, ${ }^{1}$ \\ Cláudio G. Lima-Júnior, ${ }^{3}$ Mário L. A. A. Vasconcellos, ${ }^{3}$ Sandra Rodrigues-Mascarenhas, ${ }^{2}$ and \\ Demetrius A. M. Araújo ${ }^{1}$ \\ ${ }^{1}$ Laboratório de Biotecnologia Celular e Molecular, Departamento de Biotecnologia, Centro de Biotecnologia, Universidade Federal \\ da Paraíba, Campus I, João Pessoa, PB, Brazil \\ ${ }^{2}$ Laboratório de Imunofarmacologia, Departamento de Biologia Celular e Molecular, Centro de Biotecnologia, Universidade Federal \\ da Paraíba, Campus I, João Pessoa, PB, Brazil \\ ${ }^{3}$ Laboratório de Síntese Orgânica Medicinal da Paraíba (LASOM-PB), Departamento de Química, Universidade Federal da Paraíba, \\ Campus I, João Pessoa, PB, Brazil
}

Correspondence should be addressed to Glaucia V. Faheina-Martins; glauciafaheina@yahoo.com.br and Demetrius A. M. Araújo; demetrius@cbiotec.ufpb.br

Received 27 January 2017; Revised 19 May 2017; Accepted 5 June 2017; Published 12 July 2017

Academic Editor: Manoj K. Mishra

Copyright (c) 2017 Glaucia V. Faheina-Martins et al. This is an open access article distributed under the Creative Commons Attribution License, which permits unrestricted use, distribution, and reproduction in any medium, provided the original work is properly cited.

\begin{abstract}
Inflammatory response plays an important role not only in the normal physiology but also in pathologies such as cancers. The MoritaBaylis-Hillman adducts (MBHA) are a novel group of synthetic molecules that have demonstrated many biological activities against some parasitic cells such as Plasmodium falciparum, Leishmania amazonensis, and Leishmania chagasi, and antimitotic activity against sea urchin embryonic cells was also related. However, little is known about the mechanisms induced by MBHA in inflammatory process and its relation with anticancer activity. The present work investigated the cytotoxicity of three MBHA derivatives (A2CN, A3CN, and A4CN), on human colorectal adenocarcinoma, HT-29 cells, and their anti-inflammatory activities were examined in lipopolysaccharide- (LPS-) stimulated RAW264.7 macrophage cells, being these derivatives potentially cytotoxic to HT-29 cells. Coincubation with A2CN, A3CN, or A4CN and LPS in RAW264.7 cells inhibited NO production, as well as the production of reactive oxygen species (ROS) was also repressed. The mRNA expressions of IL- $1 \beta$ and IL- 6 were significantly downregulated by such MBHA compounds in RAW264.7 cells, but only A2CN was able to inhibit the COX-2 gene expression. We also showed that MBHA compounds decreased almost to zero the production of IL-1 $\beta$ and IL-6. These findings display that such MBHA compounds exhibit anticancer and anti-inflammatory activities.
\end{abstract}

\section{Introduction}

Inflammation has been linked to cancer, but only in the last decade it has been possible to understand how inflammatory cells and other tumor stromal molecules stimulate tumor progression by creating a microenvironment that is enriched by the interleukin- $1 \beta$ (IL-1 $\beta$ ) and interleukin- 6 (IL-6) and tumor necrosis factor- $\alpha$ (TNF) cytokines, which are protagonists of chronic inflammation associated with cancers on the liver, stomach, and colon. In fact, inflammation is a condition that promotes tumor effecting on almost all types of solid cancers and then enabling many cancer features (breast, colon, and hepatocarcinoma) and promoting incipient neoplasia progression in malignant tumors complete [1]. The 
critical role of chronic inflammation in cancer was first proposed by Rudolf Virchow in 1863, when he observed the presence of leukocytes in neoplastic tissues [2-4].

Tumor microenvironment consists of tumor, immune, and inflammatory stromal cells, all of which produce cytokines, growth factors, and adhesion molecules that can promote tumor promotion and metastasis. It has been reported that there is an association between chronic inflammation and tumor progression and development, being related at least, and 15 of all types of cancers are attributed to inflammatory etiologies [5].

Actually, chronic inflammation acts as a regulator in tumor progression by many mechanisms, including accelerated cell proliferation, avoidance of death by apoptosis, and increase in angiogenesis and metastasis $[4,6]$. Such mechanism for cancer development, in the presence of chronic inflammation, involves the continuous presence of cytokines, chemokines, ROS (reactive oxygen species), oncogenes, COX-2 (cyclooxygenase-2), 5-LOX (5-lipoxygenase), and MMPs (metalloproteinases) and activation of important transcription factors such as NF- $\kappa \mathrm{B}$ (nuclear factor $-\kappa \mathrm{B}$ ), STAT-3 (signal transducer and activator of transcription 3 ), AP-1 (activator protein-1), and HIF-1 $\alpha$ (hypoxia-inducible factor 1-alpha) $[7,8]$.

IL-6 is a proinflammatory cytokine associated to inflammation, which has been involved in carcinogenesis process $[9,10]$. IL-6 modulates gene expression, as well as proliferation, survival, and angiogenesis, which has the presence of JAK- (Janus-kinase-) STAT signaling pathway [11]. It has been also shown that high IL-6 levels were detected in patients with systemic cancer, when compared to healthy patients or with benign diseases [12].

IL-6, similarly to TNF- $\alpha$, facilitates tumor development, promoting the conversion of noncancerous cells in tumor stem cells. In particular, IL-6 secretion by noncancer stem cells, at poor conditions of culture adhesion, upregulates Oct4 gene expression by activation of IL-6R/JAK/STAT3 signaling pathway [13]. These findings have led researchers to propose that IL-6 is a good therapeutic target in cancer, and many clinical trials phases I/II are evaluating IL-6 or IL-6R antibodies as therapeutic alternatives [14, 15].

Another factor that was considered to be involved in inflammation and progression of many carcinomas, including colon cancer, is COX-2, an inducible form of cyclooxygenases and a limiting enzyme in the production of prostaglandins (PEGs) $[16,17]$. COX-2 is progressively overexpressed during the stepwise sequence from adenoma to carcinoma and, in randomized, placebo-controlled trials, has shown that selective COX-2 inhibitors prevent recurrence of adenoma among patients with a history of adenoma or familial polyposis $[18,19]$.

Cancer is a serious pathology, and a substantial number of new antineoplastic agents have been discovered. Anticancer drugs that showed anti-inflammatory activity are substantially interesting, especially for the use in solid tumors, such as colon and breast cancers. The MoritaBaylis-Hillman adducts (MBHA) have been described as anticancer compounds [20-22]. It has been published that some MBHA molecules exhibited antimitotic activity against sea urchin embryonic cells [21, 22], and recently, our group demonstrated that these molecules have anticancer potential [23].

In this study, HT-29 and RAW264.7 cells were used to establish the cytotoxicity and inflammatory model in vitro, investigating the anti-inflammatory effect of $\mathrm{MBHA}$ compounds (A2CN, A3CN, and $\mathrm{A} 4 \mathrm{CN}$ ). Therefore, the cytotoxicity of MBHA compounds was firstly examined and anti-inflammatory activities were estimated as their inhibition against the production of NO, ROS, TNF- $\alpha$, IL- $1 \beta$, and IL-6 in LPS-induced RAW264.7 cells. The effects of MBHA compounds on cyclooxygenase- 2 (COX-2), IL-1 $\beta$, and IL-6 mRNA expression were also investigated in order to clarify the effect of MBHA compounds on the expression of inflammatory mediators.

\section{Material and Methods}

2.1. Material. A2CN (3-hydroxy-2-methylene-3-(4-nitrophenyl)-propanenitrile), A3CN (3-hydroxy-2-methylene-3(3-nitrophenyl)-propanenitrile), and A4CN (3-hydroxy-2methylene-3-(2-nitrophenyl)-propanenitrile) (>99\% pure) were synthesized and provided as described previously [21]. A $20 \mathrm{mM}$ stock solution of $\mathrm{A} 2 \mathrm{CN}, \mathrm{A} 3 \mathrm{CN}$, and $\mathrm{A} 4 \mathrm{CN}$ was prepared with dimethyl sulfoxide (DMSO) and freshly diluted in culture media for all in vitro experiments and in the control condition, and cells were treated using only the vehicle. The final DMSO concentration never exceeded $0.3 \%(v / v)$, in either control or treated samples. Dulbecco's Modified Eagle's medium (DMEM), 3-(4,5-dimethylthiazol2-yl)-2,5-diphenyltetrazolium bromide (MTT), lipopolysaccharide (LPS, Escherichia coli serotype 055:B5), the Griess reagent, and the primers were acquired from Sigma Chemical Co. (St. Louis, Mo, USA). Fetal bovine serum (FBS) was obtained from Cripion Biotecnologia (São Paulo, SP, Brazil). Cytokine ELISA kit was purchased from eBioscience (San Diego, CA, USA). TRIzol reagent was purchased from Invitrogen (Carlsbad, CA, USA). All other chemicals used in the experiments were commercial products of reagent grade.

2.2. Cell Culture. Murine RAW264.7 macrophages and adenocarcinoma colorectal human HT-29 cells were purchased from the Cell Bank of Rio de Janeiro (CBRJ, Rio de Janeiro, RJ, Brazil). These cells were cultured in DMEM containing $10 \%$ FBS, penicillin (100 units $/ \mathrm{mL}$ ), and streptomycin $(100 \mu \mathrm{g} / \mathrm{mL})$ in a $5 \% \mathrm{CO}_{2}$-humidified incubator at $37^{\circ} \mathrm{C}$. Cells were subcultured every 2 days, at a dilution of $1: 5$ using $0.05 \%$ trypsin $-0.02 \%$ EDTA in $\mathrm{Ca}^{2+}, \mathrm{Mg}^{2+}$-free phosphatebuffered saline solution (DPBS).

2.3. Cell Viability-MTT Assay. The cytotoxicity of RAW264.7 and HT-29 cells was evaluated using the original enzymatic reduction of MTT assay to produce formazan crystals. Raw 264.5 cells were seeded at $1 \times 10^{5}$ cells/well in 96-well tissue culture plate for 1 hour. Then, cells were exposed to different concentrations of $\mathrm{A} 2 \mathrm{CN}, \mathrm{A} 3 \mathrm{CN}$, or $\mathrm{A} 4 \mathrm{CN}(2.5,5,10$, and $20 \mu \mathrm{M})$ dissolved in the DMEM medium used as control (CTR) with $10 \%$ FBS or being necessary, the medium was incubated with LPS $(1 \mu \mathrm{g} / \mathrm{mL})$ in triplicate. HT-29 cells were 
plated overnight and treated with $\mathrm{A} 2 \mathrm{CN}, \mathrm{A} 3 \mathrm{CN}$, or $\mathrm{A} 4 \mathrm{CN}$ by $24 \mathrm{~h}(5,10,20,40,80,160$, and $320 \mu \mathrm{M})$. After $24 \mathrm{~h}$ of incubation, plates were centrifuged $(500 \times \mathrm{g}, 5 \mathrm{~min})$ and the supernatant was removed, followed by the addition of MTT solution $(0.5 \mathrm{mg} / \mathrm{mL}$ in PBS$)$ and incubation for 4 hours at $37^{\circ} \mathrm{C}$. After 4 hours, the MTT formazan product was dissolved in SDS/ $\mathrm{HCl} 0.01 \mathrm{~N}$ and absorbance was measured at $570 \mathrm{~nm}$ in reader plate ELISA (BioTek ELx800, USA) [24].

2.4. Measurement of Nitric Oxide (NO) Production. The production of $\mathrm{NO}$ was determined by assaying culture supernatant for $\mathrm{NO}^{2-}$, a major stable product of NO. Briefly, RAW264.7 cells were plated in a 96-well plate for 1 hour. Then, cells were incubated only with the DMEM medium used as control (CTR), or with LPS $(1 \mu \mathrm{g} / \mathrm{mL})$, or treated with $\mathrm{A} 2 \mathrm{CN}, \mathrm{A} 3 \mathrm{CN}$, or $\mathrm{A} 4 \mathrm{CN}$ and added with LPS $(1 \mu \mathrm{g} / \mathrm{mL})$ at $37^{\circ} \mathrm{C}$ for $22 \mathrm{~h}$. After $22 \mathrm{~h}, 100 \mu \mathrm{L}$ of each supernatant was mixed with equal amount of Griess reagent (1\% sulfanilamide, $0.1 \% \mathrm{~N}$-[naphthyl] ethylenediamine dihydrochloride, and 5\% phosphoric acid) at room temperature for $10 \mathrm{~min}$. Absorbance of the mixture was measured at $540 \mathrm{~nm}$. Nitrite concentration was calculated by comparison with a sodium nitrite standard curve [25].

2.5. Measurement of Intracellular Reactive Oxygen Species (ROS). The intracellular ROS was estimated by fluorescent probe, 2',7'-dichlorohydrofluorescein diacetate (H2-DCFDA). This dye is deacetylated by intracellular esterase and converted to nonfluorescent $2^{\prime}, 7^{\prime}$-dichlorohydrofluorescein (H2-DCF), which is rapidly oxidized to the highly fluorescent compound $2^{\prime}, 7^{\prime}$-dichlorohydrofluorescein (DCF) in the presence of ROS. The RAW264.7 cells were dispensed into 24well plates for $1 \mathrm{~h}$. Then, the cells were incubated only with the DMEM medium used as control (CTR), or with LPS $(1 \mu \mathrm{g} / \mathrm{mL})$, or treated with $\mathrm{A} 2 \mathrm{CN}, \mathrm{A} 3 \mathrm{CN}$, or $\mathrm{A} 4 \mathrm{CN}$ and added with LPS $(1 \mu \mathrm{g} / \mathrm{mL})$ at $37^{\circ} \mathrm{C}$ for $22 \mathrm{~h}$. After 22 hours of exposure, the samples were removed and centrifuged $(200 \times \mathrm{g}, 5 \mathrm{~min})$, washed with PBS at $37 \mathrm{C}$, and labeled with $\mathrm{H}_{2}$-DCFH-DA for $30 \mathrm{~min}$ in the dark conditions, at $37^{\circ} \mathrm{C}$. Then, cells were washed with PBS and analyzed by flow cytometer in FACSCalibur (Becton Dickinson, USA) at FL1-H filter. A minimum of 10,000 events were acquired for each sample.

2.6. Measurement of $I L-1, I L-6$, and TNF Production. Cells were cultured in a 24 -well plate for $24 \mathrm{~h}$. Then, the cells were incubated only with the DMEM medium used as control (CTR), with LPS $(1 \mu \mathrm{g} / \mathrm{mL})$, or treated with $\mathrm{A} 2 \mathrm{CN}, \mathrm{A} 3 \mathrm{CN}$, or A4CN and added with LPS $(1 \mu \mathrm{g} / \mathrm{mL})$ at $37^{\circ} \mathrm{C}$ for $22 \mathrm{~h}$. After treatment, RAW264.7 cell culture supernatants were collected and stored at $-80^{\circ} \mathrm{C}$ until analysis. Cytokine production was measured with commercial mouse ELISA kits (eBioscience ELISA kits, CA, USA) following the manufacturer's protocol.

2.7. RNA Extraction. RAW264.7 cells were cultured in 6-well plates $\left(1 \times 10^{6}\right.$ cells $\left./ \mathrm{mL}\right)$ for $1 \mathrm{~h}$ and incubated only with the DMEM medium used as control (CTR), or with LPS $(1 \mu \mathrm{g} /$ $\mathrm{mL}$ ), or treated with $10 \mu \mathrm{M}$ of $\mathrm{A} 2 \mathrm{CN}, \mathrm{A} 3 \mathrm{CN}$, or $\mathrm{A} 4 \mathrm{CN}$ and added with LPS $(1 \mu \mathrm{g} / \mathrm{mL})$ for $22 \mathrm{~h}$. Briefly, RNA extraction from treated or nontreated cells was performed using $1.0 \mathrm{~mL}$ of TRIzol for each $1 \times 10^{6}$ cells of sample according to the manufacturer's recommendation or using RNeasy mini kit (Qiagen, CA, USA). RNA integrity was assayed by agarose gel electrophoresis and treated with DNAse (RQ1 RNAse free DNAse-Promega, USA). cDNA was performed using SuperScript III Platinum one-step qRT-PCR Systems (Invitrogen, USA).

2.8. Quantitative Real-Time Polymerase Chain Reaction ( $q$ PCR) Analysis. To evaluate mRNA expression levels, total RNA was isolated from RAW264.7 cells with TRIzol reagent. Quantitative PCR was performed in a SuperScript ${ }^{\circledR}$ III Platinum ${ }^{\circledR}$ One-Step qRT-PCR kit (Invitrogen, USA), under the Bio-Rad Real-Time PCR Detection System (Bio-Rad Laboratories Inc., USA), and the results were analyzed with the CFX manager optical system software supplied with the equipment. The housekeeping gene GAPDH was used as an internal standard to quantify the levels of parameters of q-PCR reactions. Such reactions were as the following: $50^{\circ} \mathrm{C}$ for $2 \mathrm{~min}, 95^{\circ} \mathrm{C}$ for $5 \mathrm{~min}$ for one cycle, then $95^{\circ} \mathrm{C}$ for $15 \mathrm{~s}, 64^{\circ} \mathrm{C}$ for $30 \mathrm{~s}$, and $72^{\circ} \mathrm{C}$ for $30 \mathrm{~s}$ for 50 cycles. The fluorescence signal was detected at the end of each cycle. The $2^{-\Delta \Delta C T}$ method was performed to analyze the results. The primers used in the experiment are shown in Table 1.

2.9. Statistical Analysis. The data are expressed as mean \pm SEM from three replicates per treatment. Data were analyzed by one-way ANOVA followed by the Newman-Keuls analysis by multiple comparison tests. The level of significance was set at $p<0.05$. Data of all the results in this study were obtained from at least three independent experiments with a similar pattern.

\section{Results}

3.1. Effect of MBHA on Cell Viability. We first studied the effect cytotoxic of $\mathrm{A} 2 \mathrm{CN}, \mathrm{A} 3 \mathrm{CN}$, and $\mathrm{A} 4 \mathrm{CN}$ on HT-29 tumor cells (Figure 1). The molecules exhibited cytotoxicity for cells after $24 \mathrm{~h}$, with $\mathrm{CI}_{50}$ of $54 \pm 7.4,134 \pm 7.1$, and 231 $\pm 7.5 \mu \mathrm{M}$ for $\mathrm{A} 2 \mathrm{CN}, \mathrm{A} 3 \mathrm{CN}$, and $\mathrm{A} 4 \mathrm{CN}$, respectively. However, while adducts were tested on RAW264.7 cells, these compounds did not affect the cell viability when assayed without or with incubation of $1 \mu \mathrm{g} / \mathrm{mL}$ LPS (Figure 2).

3.2. Effect of MBHA on NO Production from LPS-Induced RAW264.7 Cells. Using subcytotoxic concentrations of MBHA for HT-29 cells, we tested the anti-inflammatory activity of $\mathrm{A} 2 \mathrm{CN}, \mathrm{A} 3 \mathrm{CN}$, and $\mathrm{A} 4 \mathrm{CN}$ incubated with LPS $(1 \mu \mathrm{g} / \mathrm{mL})$ on RAW264.7 cells. NO production, measured as nitrite, was increased dramatically compared with the control group. To determine the effect of MBHA on NO production, different concentrations of $\mathrm{A} 2 \mathrm{CN}, \mathrm{A} 3 \mathrm{CN}$, and $\mathrm{A} 4 \mathrm{CN}$ $(2.5 \mu \mathrm{M}, 5 \mu \mathrm{M}, 10 \mu \mathrm{M}$, and $20 \mu \mathrm{M}$ incubated with LPS) were plated with the cells for $22 \mathrm{~h}$. A concentration-dependent inhibition of NO generation was observed. The coincubation of the cells with LPS and A2CN, A3CN, or A4CN decreased drastically to basal concentrations (Figure 3). 
Table 1: Primer sequences used.

\begin{tabular}{|c|c|c|c|}
\hline Gene & Primer sequence & Product size & NM code \\
\hline IL-6 & $\begin{array}{l}\text { F: 5'-GGGACTGATGCTGGTGACAA-3' } \\
\text { R: 5'-TAACGCACTAGGTTTGCCGA-3' }\end{array}$ & $599 \mathrm{pb}$ & NM_031168.1 \\
\hline IL- $1 \beta$ & $\begin{array}{l}\text { F: 5'-AACCTTTGACCTGGGCTGTC-3' } \\
\text { R: 5'-AATGGGAACGTCACACACCA-3' }\end{array}$ & $253 \mathrm{pb}$ & NM_008361.3 \\
\hline COX-2 & $\begin{array}{l}\text { F: 5'-CGTAGCAGATGACTGCCCAA-3' } \\
\text { R: 5'-TCTCAGGGATGTGAGGAGGG-3' }\end{array}$ & $383 \mathrm{pb}$ & NM_011198.3 \\
\hline GAPDH-c & $\begin{array}{l}\text { F: 5'-GACCACAGTCCATGCCATCA-3' } \\
\text { R: 5'-TAGGGCCTCTCTTGCTCAGT-3' }\end{array}$ & $535 \mathrm{pb}$ & NM_0080084.2 \\
\hline
\end{tabular}

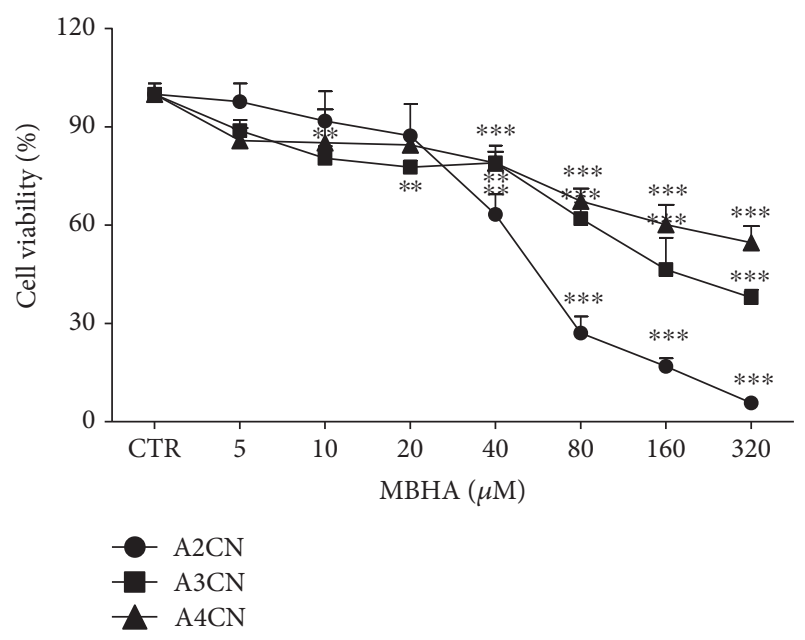

Figure 1: Cell viability of HT-29 cells incubated for $24 \mathrm{~h}$ with MBHA compounds (A2CN, $\mathrm{A} 3 \mathrm{CN}$, or $\mathrm{A} 4 \mathrm{CN}$ ). Data were obtained by MTT assay. CTR, cells cultured without MBHA compounds (means $0 \mu \mathrm{M}$ ). Cells were treated in a medium supplemented with $10 \%$ of FBS. Results are mean \pm SEM of three independent experiments performed in triplicate. ${ }^{* *} p<0.01$, ${ }^{* * *} p<0.001$ compared with CTR. Data were analyzed by ANOVA followed by Newman-Keuls post hoc test.

3.3. Production of ROS by LPS-Induced RAW264.7 Cells Treated with $M B H A$. It has been reported that mitochondrial ROS molecules act to trigger the production of inflammatory cytokines [26, 27]. Therefore, we evaluated the participation of adducts $\mathrm{A} 2 \mathrm{CN}, \mathrm{A} 3 \mathrm{CN}$, and $\mathrm{A} 4 \mathrm{CN}$ in the production of ROS in RAW264.7 cells. As seen in Figure 4, all MBHA compounds decreased the ROS production induced by LPS from $2.5 \mu \mathrm{M}$ to the highest tested concentration.

3.4. Effect of MBHA on $m R N A$ Expression of $I L-1, I L-6$, and COX-2. As shown in Figure 5, the MBHA compounds inhibited significantly the upregulation of LPS-induced mRNA expression of IL-1 (Figure 5(a)) and IL-6 (Figure 5(b)) showing almost complete suppression induced by all adducts tested. However, the inhibition of COX-2 gene occurred only in cells treated with A2CN (Figure 5(c)).

3.5. Effect of MBHA on $I L-1, I L-6$, and TNF Production from LPS-Induced RAW264.7. LPS is a well-known potent activator of inflammatory cytokines like NO, PGE2, TNF- $\alpha$, IL-1, and IL-6. When RAW264.7 cells were cultured with A2CN,

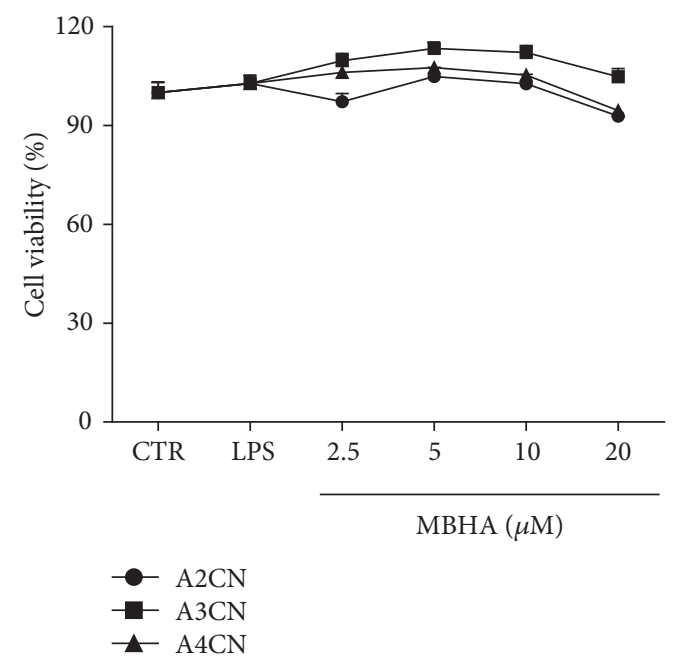

Figure 2: Cell viability of RAW264.7 cells incubated for $22 \mathrm{~h}$ with MBHA (A2CN, A3CN, or A4CN). Data were obtained by MTT assay. Cells were treated for $22 \mathrm{~h}$. CTR, cells without LPS and MBHA compounds. LPS, cells incubated with LPS $(1 \mu \mathrm{g} / \mathrm{mL})$. MBHA $(\mu \mathrm{M})$ means cells cultured with $\mathrm{A} 2 \mathrm{CN}, \mathrm{A} 3 \mathrm{CN}$, or $\mathrm{A} 4 \mathrm{CN}$ as indicated. Results are mean \pm SEM of three independent experiments of percentage of cell viability performed in triplicate and were analyzed by ANOVA followed by Newman-Keuls post hoc test.

$\mathrm{A} 3 \mathrm{CN}$, or $\mathrm{A} 4 \mathrm{CN}$ compounds for $22 \mathrm{~h}$, a total inhibition of IL-1 (Figure 6(a)) and IL-6 (Figure 6(b)) productions were observed at all concentrations tested. However, TNF levels were not altered (Figure 6(c)). We also observed that incubating only an adduct compound separately, we did not verify any effect on cytokine secretion in RAW264.7 cells.

\section{Discussion}

The MBHA compounds are a class of molecules which have shown high anticancer activity against a variety of cancer cell lines [20-23]. Therefore, it is important to carry on the research and discoveries of new activities of such MBHA molecules.

Inflammation is present in cancers that have arisen without precancerous inflammation [28]. The inflammatory state is required to maintain and promote cancer progression with complete malignant phenotype, such as tissue remodeling, 


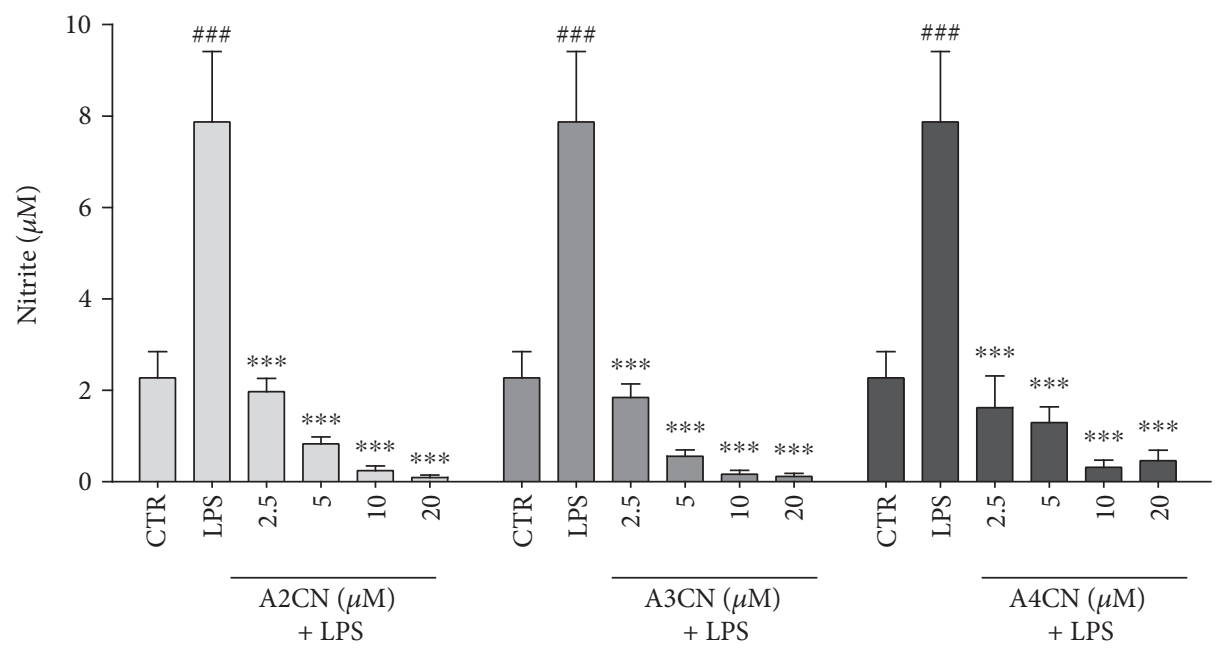

FIGURE 3: Evaluation of LPS-induced NO production incubated without compounds or coincubated with increasing concentrations of A2CN, A3CN, or A4CN for $22 \mathrm{~h}$. LPS was incubated at $1 \mu \mathrm{g} / \mathrm{mL}$. CTR, cells without LPS and MBHA compounds. LPS, cells incubated with LPS ( $1 \mu \mathrm{g} /$ $\mathrm{mL})$. NO production was measured using the media and Griess reagent. ${ }^{\# \#} p<0.001$, compared to CTR. ${ }^{* * *} p<0.001$, compared to LPS + MBHA compound groups. Data were analyzed by ANOVA followed by Newman-Keuls post hoc test.

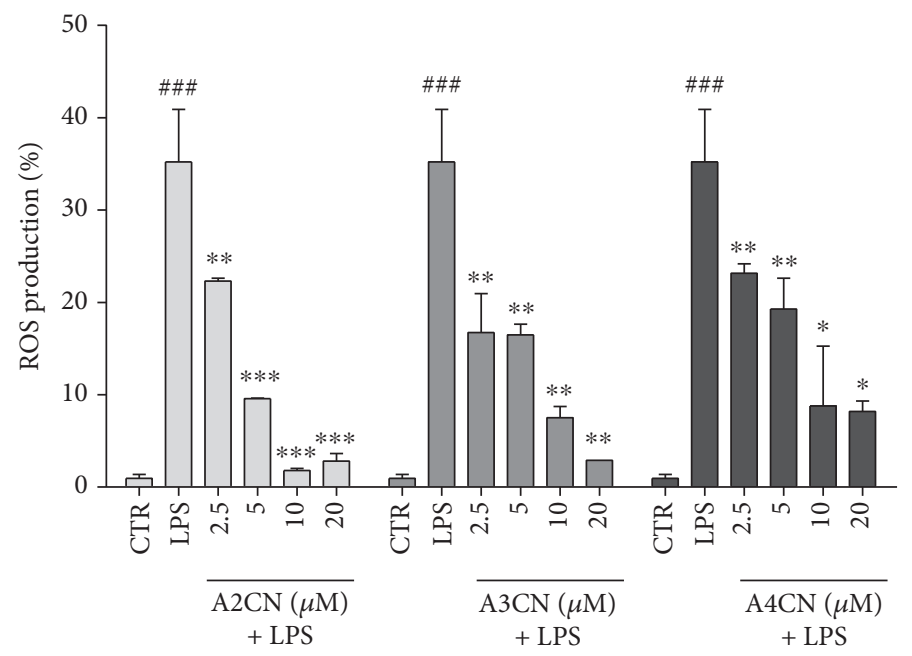

Figure 4: Effect of A2CN, A3CN, and A4CN on ROS production by RAW264.7 macrophage cells stimulated with LPS (1 $\mu \mathrm{g} / \mathrm{mL})$ for $22 \mathrm{~h}$ of incubation. CTR means cells without LPS and MBHA compound incubation. LPS, cells incubated with LPS (1 $\mu \mathrm{g} / \mathrm{mL})$. Cells were labeled with $\mathrm{H} 2$-DCFH-DA, and ROS production was quantified by flow cytometry in FL-1 channel. Results represented mean \pm SEM of three experiments in triplicate. Data were analyzed by ANOVA, followed Newman-Keuls post hoc test. ${ }^{\# \# ~} p<0.001$, compared to CTR group. ${ }^{*} p<0.05,{ }^{* *} p<0.01$, and ${ }^{* * *} p<0.001$, compared to LPS + MBHA compound groups.

angiogenesis, metastasis, and suppression of innate immune response [29]. In our recent study, we demonstrated that $\mathrm{A} 2 \mathrm{CN}, \mathrm{A} 3 \mathrm{CN}$, and $\mathrm{A} 4 \mathrm{CN}$ exhibited antileukemic activity [23]. In this study, we showed that $\mathrm{A} 2 \mathrm{CN}$, $\mathrm{A} 3 \mathrm{CN}$, and $\mathrm{A} 4 \mathrm{CN}$ compounds reduced the cell viability of HT-29 cell line (Figure 1), according to previous data published by our group [23], confirming that these molecules have anticancer potential. It was reported that MBHA compounds demonstrated a poor cytotoxic effect in normal cells and these compounds have close relationship between inflammation and cancer [25]. That way, this study was designed to explore the anti-inflammatory effects of AMBH using RAW264.7 macrophage cells. Actually, discoveries of molecules which are cytotoxic to tumor cells and inhibit inflammatory process have great importance at advancement of therapies for solid tumors.

Initially, we examined the effects of MBHA compounds on cell viability in RAW264.7 macrophage cells. The MTT assay showed that treatment of $\mathrm{A} 2 \mathrm{CN}, \mathrm{A} 3 \mathrm{CN}$, and $\mathrm{A} 4 \mathrm{CN}$ at concentrations of $2.5-20 \mu \mathrm{M}$ did not exhibit any cytotoxic effect in RAW264.7 cells (Figure 2). Based on the results above, we selected these noncytotoxic concentrations for such MBHA compounds, which were further examined for their anti-inflammatory properties. 


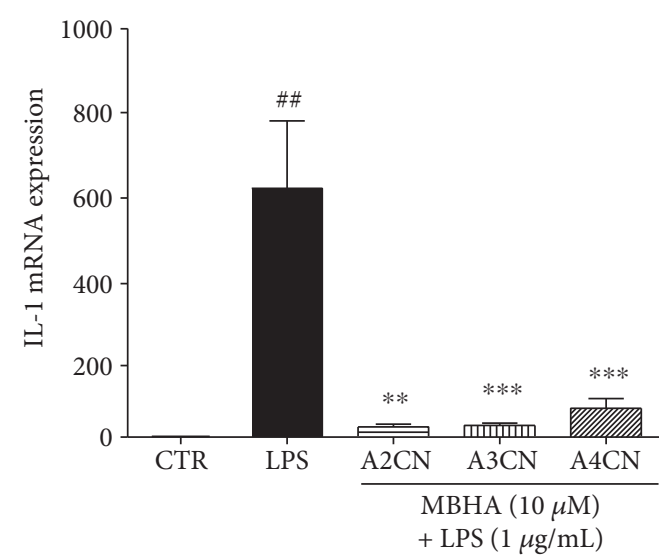

(a)

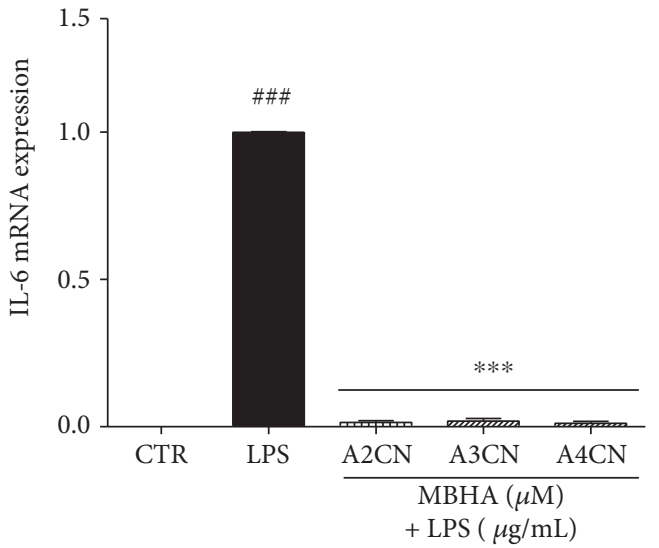

(b)

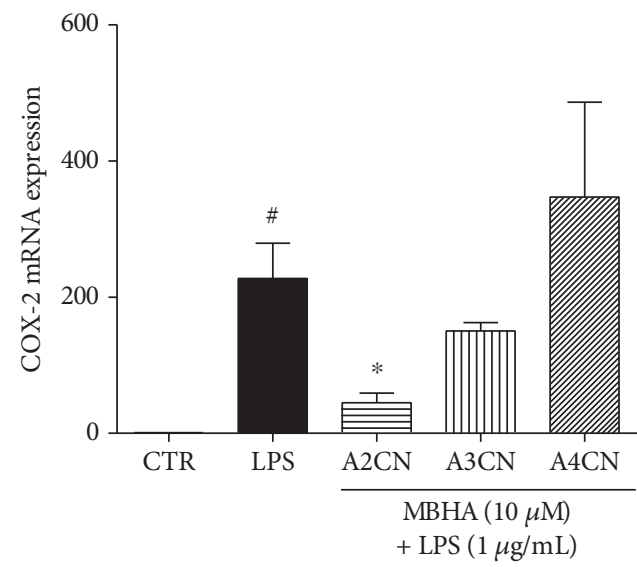

(c)

FiguRE 5: Effect on the mRNA expression of inflammatory mediators: IL-1 (a), IL-6 (b), and COX-2 (c). Cells were incubated with A2CN, $\mathrm{A} 3 \mathrm{CN}$, or $\mathrm{A} 4 \mathrm{CN}(10 \mu \mathrm{M})$ in the presence of LPS $(1 \mu \mathrm{g} / \mathrm{mL})$ for $22 \mathrm{~h}$. CTR means cells without LPS and MBHA compound incubation. LPS, cells incubated with LPS $(1 \mu \mathrm{g} / \mathrm{mL})$. The mRNA levels were determined by quantitative RT-PCR using $2^{-\Delta \Delta c t}$ method. Results were analyzed by unpaired $t$-test. ${ }^{\#} p<0.05,{ }^{\# \#} p<0.01$, and ${ }^{\# \# \#} p<0.001$, compared to CTR group and ${ }^{*} p<0.05,{ }^{* *} p<0.01$, and ${ }^{* * * *} p<0.001$ compared to LPS + MBHA compound groups.

One of the most prominent phenomena observed in inflammation event is the progressive increase of NO. This radical is involved in inflammation-induced human diseases such as cancer, rheumatoid arthritis, diabetes, septic shock, and cardiovascular diseases [17]. In this work, $\mathrm{A} 2 \mathrm{CN}$, $\mathrm{A} 3 \mathrm{CN}$, and $\mathrm{A} 4 \mathrm{CN}$ compounds completely inhibited NO production in RAW264.7 cells stimulated with LPS, even at low concentrations, $2.5 \mu \mathrm{M}$. These results suggest that $\mathrm{MBHA}$ compounds can exert an anti-inflammatory effect. The NO inhibition did not change the cell viability according to the data obtained after $22 \mathrm{~h}$ treatment with $20 \mu \mathrm{M}$ MBHA compounds (Figure 2).

Chronic inflammation is often accompanied by increased production of reactive oxygen species (ROS). The proneoplastic activity of ROS can induce DNA damage [19]. Agents that prevent the formation of ROS can also inhibit the induction of DNA damage, mutagenesis, and cell transformation. The adducts $\mathrm{A} 2 \mathrm{CN}, \mathrm{A} 3 \mathrm{CN}$, and $\mathrm{A} 4 \mathrm{CN}$ incubated with LPS almost completely inhibited ROS production in RAW264.7 cells, even at low concentration experienced, and this result together with the reduced synthesis of NO provoked by such compounds, clearly demonstrate the antiredox potential of
MBHA molecules. Additionally, we also showed that MBHA compounds in a dose-dependent manner reduced LPSinduced ROS production in RAW264.7 cells. In fact, ROS, including hydrogen peroxide and superoxide anions, are potent inducers of various signaling pathways encompassing MAPKs and JAK-STAT pathways [30].

For a more clear understanding of $\mathrm{A} 2 \mathrm{CN}, \mathrm{A} 3 \mathrm{CN}$, and $\mathrm{A} 4 \mathrm{CN}$ effects, we evaluated whether the change in the levels of mRNA for the genes IL-1 $\beta$ and IL-6 in RAW264.7 cells stimulated with LPS and treated with $10 \mu \mathrm{M}$ of all MBHA might occur. These compounds inhibited the gene expression of IL- $1 \beta$ and IL- 6 to basal levels (incubations without LPS stimulation). On the other hand, these genes were detected only when the cells were stimulated with LPS (Figures 5(a) and 5(b)). Numerous studies have indicated that tumor cells exhibit constitutive production of TNF- $\alpha$ proinflammatory cytokines, IL- $1 \alpha$, IL-6, and GM-CSF (macrophage-granulocyte colonystimulating factor) [4, 27]. In this study, inhibition of IL-1 and IL-6 genes in inflammatory cells suggests that blocking can also happen in tumor cells, which produce these cytokines, favoring the tumor progression. 


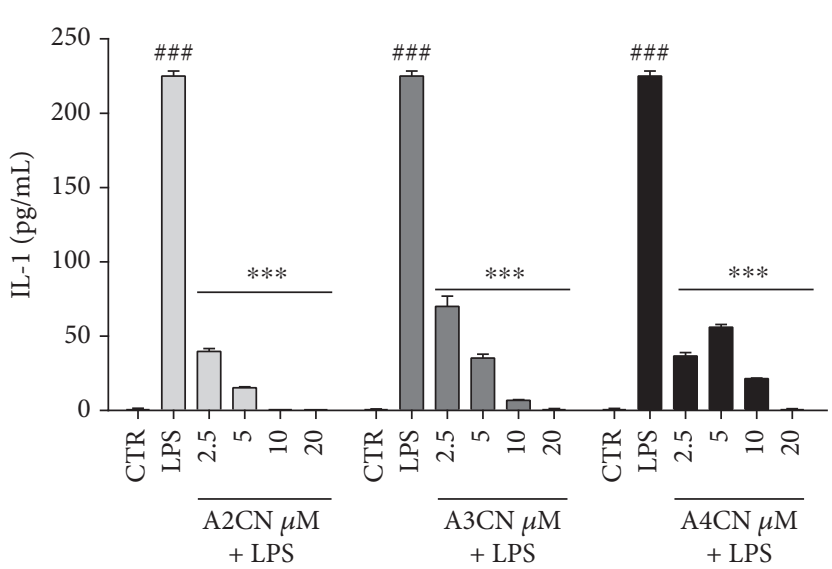

(a)

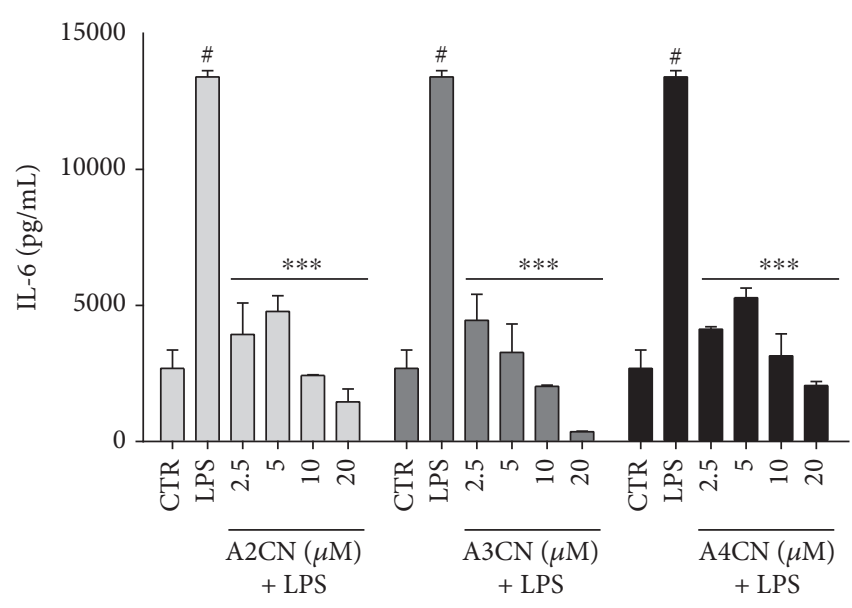

(b)

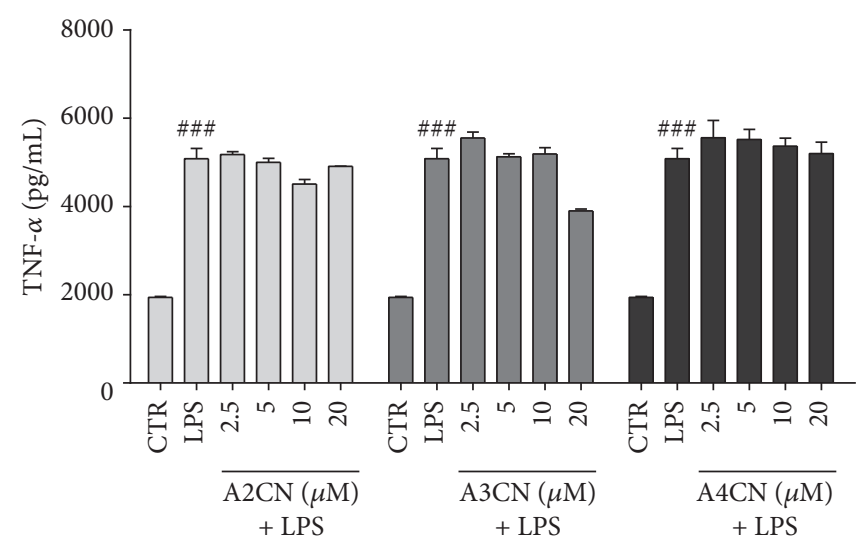

(c)

Figure 6: Effects of A2CN, A3CN, and A4CN compounds on inflammatory cytokine production: IL-1 (a), IL-6 (b), and TNF- $\alpha$ (c). CTR means cells without LPS and MBHA compound incubation. LPS, cells incubated with LPS $(1 \mu \mathrm{g} / \mathrm{mL})$. Cells were incubated with A2CN, $\mathrm{A} 3 \mathrm{CN}$, or $\mathrm{A} 4 \mathrm{CN}(2.5-20 \mu \mathrm{M})$ in the presence of LPS $(1 \mu \mathrm{g} / \mathrm{mL})$ for $22 \mathrm{~h}$, as indicated. Reported values are the mean \pm SEM of three independent experiments in triplicate. The dates were analyzed by ANOVA followed by Newman-Keuls post hoc test. ${ }^{\#} p<0.05$, $\#^{\# \#} p<0.001$, compared to CTR group. ${ }^{* * *} p<0.001$, compared to LPS + MBHA compound groups.

COX-2 is an inducible enzyme and can be affected by mitogens, growth factors, and hormones, which are of great importance in tumorigenesis. COX-2 can also induce VEGF production, contributing to angiogenesis, as well as increases metalloproteinases, which improve the invasion of tumor vessels and reduce the production of antiangiogenic cytokines, such as IL-12. It has also been shown that COX-2 increases the resistance to apoptosis [31]. COX-2 selective inhibitors are better tolerated at therapeutic doses, not inhibiting COX-1. These COX-2 selective inhibitors have helped to suppress tumor growth and malignant transformation, by stimulating apoptosis, and inhibit the VEGF production by reducing angiogenesis [31, 32]. In this work, we demonstrated that only $\mathrm{A} 2 \mathrm{CN}$ at a concentration of $10 \mu \mathrm{M}$ was able to decrease the expression of COX-2 in RAW264.7 cells stimulated with LPS (Figure 5). In this case, position of the nitro group isomer influenced the molecule effectiveness to inhibit the enzyme gene expression.

Once it has recently demonstrated the action of mitochondrial ROS (MTROS) as signaling molecules to trigger the production of proinflammatory cytokines such as IL-6 and TNF- $\alpha$ [30], we sought to demonstrate the action of MBHA in the production of these inflammatory cytokines in RAW264.7 cells stimulated with LPS. The data obtained by ELISA showed that cytokine production by RAW264.7 cells after stimulation with LPS was greatly altered. The release of IL- $1 \beta$ and IL- 6 was completely blocked after $22 \mathrm{~h}$ by addition of $\mathrm{A} 2 \mathrm{CN}, \mathrm{A} 3 \mathrm{CN}$, or $\mathrm{A} 4 \mathrm{CN}$, even at the lowest concentration of $2.5 \mu \mathrm{M}(p<0.001)$. However, the cytokine TNF- $\alpha$ was not affected by any of the tested molecules. This result demonstrates a potent anti-inflammatory effect in vitro in subcytotoxic concentrations. It is suggested that the inhibition of IL- 6 production is mediated by the inhibition of IL- $1 \beta$.

Direct evidence has shown that IL1- $\beta$ plays an important role in multiple myeloma, and when released, this cytokine induces IL- 6 production by bone marrow stromal cells and acts as an autocrine growth factor for myeloma cells [4, 33]. IL1- $\beta$ also regulates HIF- $1 \alpha$ protein, involving an inflammatory signaling pathway to NF- $\kappa \mathrm{B}$ and $\mathrm{COX}-2$, resulting in the upregulation of VEGF (vascular endothelial growth factor), a potent angiogenic factor needed for metastasis and for tumor 
growth [34]. IL-6 is another proinflammatory cytokine that has been involved in carcinogenesis associated with inflammation $[9,10]$. This cytokine modulates the expression of genes involved in the proliferation, survival, and angiogenesis by signaling via the Janus-kinase- (JAK-) STAT [11].

As far as we know, the data shown on this paper shows for the first time an anti-inflammatory activity of $\mathrm{A} 2 \mathrm{CN}$, $\mathrm{A} 3 \mathrm{CN}$, and $\mathrm{A} 4 \mathrm{CN}$ compounds, which especially blocks the IL-1 and IL-6 cytokines and consequently may reduce the progression and growth of tumors.

In addition, we showed that $\mathrm{A} 2 \mathrm{CN}$ compound proved to be the most effective molecule in the anti-inflammatory action among the tested isomers because this adduct was also able to inhibit the expression of COX-2 gene. This considerable A2CN activity is very promising because it contributes to the anticancer activity, recently demonstrated by our group in several cancer cell lines [23], and corroborates the potent antiparasitic activity against Leishmania, Plasmodium and, Trypanosoma, widely reported in the literature.

Most antineoplastic actions with nitro (nitacrine, 1-(1,5dicloropentano-3-yl)-4-nitrobenzene) and antiparasitic (metronidazole, tinidazole, secnidazole, benznidazole, and nifurtimox) are dependent upon the enzyme bioreduction process group nitro, strong electron acceptor, as probable mechanism of action. The passage of these molecules generally occurs by passive diffusion in the membrane, and the bioreduction process generates a lot of free radicals' short life, resulting in peroxidation of biological and protein membranes, causing damage to the DNA [35]. Nimesulide is an example of nitro compound, nitrobenzene's class of derivatives, used in anti-inflammatory therapy, and extensive clinical application. Thus, the nitro group present in molecules tested in this study and their position contribute to their cytotoxic activity on tumor cells, as well as for its antiinflammatory activity.

The increase production of free radicals occurs due to decreased activity of cellular defense systems. The balance in macrophage stimulated with LPS is disrupted by excessive production of ROS in a mutual induction pattern. In this study, we also observed that $\mathrm{A} 2 \mathrm{CN}, \mathrm{A} 3 \mathrm{CN}$, and $\mathrm{A} 4 \mathrm{CN}$ dose dependently reduced LPS-induced ROS production in RAW264.7 cells. In fact, ROS, including hydrogen peroxide and superoxide anions, are potent inducers of various signaling pathways encompassing MAPKs and JAK-STAT pathways [36]. Further work is necessary to investigate the precise correlation between ROS and JAK/STAT signaling.

\section{Conflicts of Interest}

The authors declare that there is no conflict of interest regarding the publication of this paper.

\section{References}

[1] Y. Cao, "Tumor angiogenesis and therapy," Biomedicine and Pharmacotherapy, vol. 59, pp. 340-343, 2005.

[2] A. Mantovani, P. Allavena, A. Sica, and F. Balkwill, "Cancerrelated inflammation,” Nature, vol. 454, pp. 436-444, 2008.
[3] B. B. Aggarwal, R. V. Vijayalekshmi, and B. Sung, "Targeting inflammatory pathways for prevention and therapy of cancer: short-term friend, long-term foe," Clinical Cancer Research, vol. 15, pp. 425-430, 2009.

[4] G. Sethi, M. K. Shanmugam, L. Ramachandran, A. L. Kumar, and V. Tergaonkar, "Multifaceted link between cancer and inflammation," Bioscience Reports, vol. 32, pp. 1-15, 2012.

[5] F. Colotta, P. Allavena, A. Sica, C. Garlanda, and A. Mantovani, "Cancer-related inflammation, the seventh hallmark of cancer: links to genetic instability," Carcinogenesis, vol. 30, pp. 1073-1081, 2009.

[6] B. B. Aggarwal, S. Shishodia, S. K. Sandur, M. K. Pandey, and G. Sethi, "Inflammation and cancer: how hot is the link?" Biochemical Pharmacology, vol. 72, pp. 1605-1616, 2006.

[7] B. B. Aggarwal and P. Gehlot, "Inflammation and cancer: how friendly is the relationship for cancer patients?" Current Opinion in Pharmacology, vol. 9, pp. 351-369, 2009.

[8] F. Balkwill and A. Mantovani, "Cancer and inflammation: implications for pharmacology and therapeutics," Clinical Pharmacology and Therapeutics, vol. 87, pp. 401-406, 2010.

[9] D. S. Hong, L. S. Angelo, and R. Kurzrock, "Interleukin-6 and its receptor in cancer: implications for translational therapeutics," Cancer, vol. 110, pp. 1911-1928, 2007.

[10] W. E. Naugler and M. Karin, "The wolf in sheep's clothing: the role of interleukin-6 in immunity, inflammation and cancer," Trends in Molecular Medicine, vol. 14, pp. 109-119, 2008.

[11] W. W. Lin and M. Karin, "A cytokine-mediated link between innate immunity, inflammation, and cancer," The Journal of Clinical Investigation, vol. 117, pp. 1175-1183, 2007.

[12] G. Landskron, M. D. Fuente, P. Thuwajit, C. Thuwajit, and M. A. Hermoso, "Chronic inflammation and cytokines in the tumor microenvironment," Journal of Immunology Research, vol. 2014, pp. 1-19, 2014.

[13] S.-Y. Kim, J. W. Kang, X. Song et al., "Role of the IL-6-JAK1STAT3-Oct-4 pathway in the conversion of non-stem cancer cells into cancer stem-like cells," Cell Signaling, vol. 25, pp. 961-969, 2013.

[14] J. Coward, H. Kulbe, P. Chakravarty et al., "Interleukin-6 as a therapeutic target in human ovarian cancer," Clinical Cancer Research, vol. 17, pp. 6083-6096, 2011.

[15] R. Kurzrock, P. M. Voorhees, C. Casper et al., "A phase I, open-label study of siltuximab, an anti-IL-6 monoclonal antibody, in patients with B-cell non-Hodgkin lymphoma, multiple myeloma, or Castleman disease," Clinical Cancer Research, vol. 19, pp. 3659-3670, 2013.

[16] Y.-Z. Yang, Y.-Z. Tang, and Y.-H. Liu, "Wogonoside displays anti-inflammatory effects through modulating inflammatory mediator expression using RAW264.7 cells," Journal of Ethnopharmacology, vol. 48, pp. 271-276, 2013.

[17] M. Fang, S. Y. Lee, S. M. Park et al., “Anti-inflammatory potential of Phaseolus calcaratus Roxburgh, an oriental medicine, on LPS-stimulated RAW 264.7 macrophages," Journal of Pharmacy and Pharmacology, vol. 63, pp. 120-128, 2011.

[18] A. T. Chan, S. Ogino, and C. S. Fuchs, "Aspirin and the risk of colorectal cancer in relation to the expression of COX-2," The New England Journal of Medicine, vol. 356, pp. 2131-2142, 2007.

[19] L. J. Marnett, "Oxyradicals and DNA damage," Carcinogenesis, vol. 21, pp. 361-370, 2000.

[20] L. K. Kohn, C. H. Pavam, D. Veronense, F. Coelho, J. E. De Carvalho, and W. P. Almeida, "Antiproliferative effect of Baylis-Hillman adducts and a new phthalide derivative on 
human tumor cell lines," European Journal of Medicinal Chemistry, vol. 41, pp. 738-744, 2006.

[21] J. C. A. Leite, C. G. L. Junior, F. P. L. Silva, S. C. O. Sousa, M. L. A. A. Vasconcellos, and L. F. Marques-Santos, "Antimitotic activity on sea urchin embryonic cells of seven antiparasitic Morita-Baylis-Hillman adducts: a potential new class of anticancer drugs," Medicinal Chemistry, vol. 8, pp. 1003-1011, 2012.

[22] C. G. Lima-Junior and M. L. A. A. Vasconcellos, "MoritaBaylis-Hillman adducts: biological activities and potentialities to the discovery of new cheaper drugs," Bioorganic \& Medicinal Chemistry, vol. 20, pp. 3954-3971, 2012.

[23] C. G. Lima-Junior, G. V. Faheina-Martins, C. C. Bomfim et al., "Synthesis, cytotoxic activity on leukemia cell lines and quantitative structure-activity relationships (QSAR) studies of Morita-Baylis-Hillman adducts," Medicinal Chemistry, vol. 8, pp. 602-612, 2016.

[24] G. V. Faheina Martins, A. L. Silveira, B. C. Cavalcanti et al., "Antiproliferative effects of lectins from Canavalia ensiformis and Canavalia brasiliensis in human leukemia cell lines," Toxicology in Vitro, vol. 26, pp. 1161-1169, 2012.

[25] M. Comalada, I. Ballester, E. Bailon et al., "Inhibition of pro-inflammatory markers in primary bone marrow-derived mouse macrophages by naturally occurring flavonoids: analysis of the structure-activity relationship," Biochemical Pharmacology, vol. 72, pp. 1010-1021, 2006.

[26] K. Nakahira, J. A. Haspel, V. A. K. Rathinam et al., "Autophagy proteins regulate innate immune responses by inhibiting the release of mitochondrial DNA mediated by the NALP3 inflammasome," Nature Immunology, vol. 12, pp. 222-230, 2011.

[27] R. Zhou, A. S. Yazdi, P. Menu, and J. Tschoop, "A role for mitochondria in NLRP3 inflammasome activation," Nature, vol. 469, pp. 221-225, 2011.

[28] M. Philip, D. A. Rowley, and H. Schreiber, "Inflammation as a tumor promoter in cancer induction," Seminars in Cancer Biology, vol. 14, pp. 433-439, 2004.

[29] S. I. Grivennikov, F. R. Greten, and M. Karin, "Immunity, inflammation, and cancer," Cell, vol. 140, pp. 883-899, 2010.

[30] A. C. Bulua, A. Simon, R. Maddipati et al., "Mitochondrial reactive oxygen species promote production of proinflammatory cytokines and are elevated in TNFR1-associated periodic syndrome (TRAPS)," The Journal of Experimental Medicine, vol. 208, pp. 519-533, 2011.

[31] M. J. Toomey, J. F. Murphy, and K. C. Colon, "Cox-2, VEGF and tumor angiogenesis," The Surgeon, vol. 7, pp. 174-180, 2009.

[32] J. X. Ma, Y. L. Sun, Y. Q. Wang, H. Y. Wu, J. Jin, and X. F. Yu, "Triptolide induces apoptosis and inhibits the growth and angiogenesis of human pancreatic cancer cells by downregulating COX-2 and VEGF," Oncology Research, vol. 20, pp. 359-368, 2013.

[33] J. A. Lust, M. Q. Lacy, S. R. Zeldenrust et al., "Induction of a chronic disease state in patients with smoldering or indolent multiple myeloma by targeting interleukin $1 \beta$-induced interleukin 6 production and the myeloma proliferative component," Mayo Clinic Proceedings, vol. 84, pp. 114-122, 2009.

[34] Y. J. Jung, J. S. Isaacs, S. Lee, J. Trepel, and L. Neckers, "IL-1 $\beta$ mediated up-regulation of HIF- $1 \alpha$ via an $\mathrm{NF} \kappa \mathrm{B} / \mathrm{COX}-2$ pathway identifies HIF-1 as a critical link between inflammation and oncogenesis," The FASEB Journal, vol. 17, pp. 2115-2117, 2003.

[35] F. R. Paula, S. H. P. Serrano, and L. C. Tavares, "Aspectos mecanísticos da bioatividade e toxicidade de nitrocompostos," Quim Nova, vol. 32, pp. 1013-1020, 2009.

[36] Z. Qi, F. Yin, L. Lu et al., "Baicalein reduces lipopolysaccharideinduced inflammation via suppressing JAK/STATs activation and ROS production," Inflammation Research, vol. 62, pp. 1-11, 2013. 


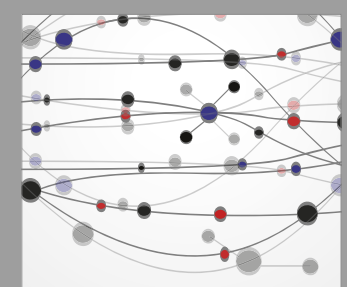

The Scientific World Journal
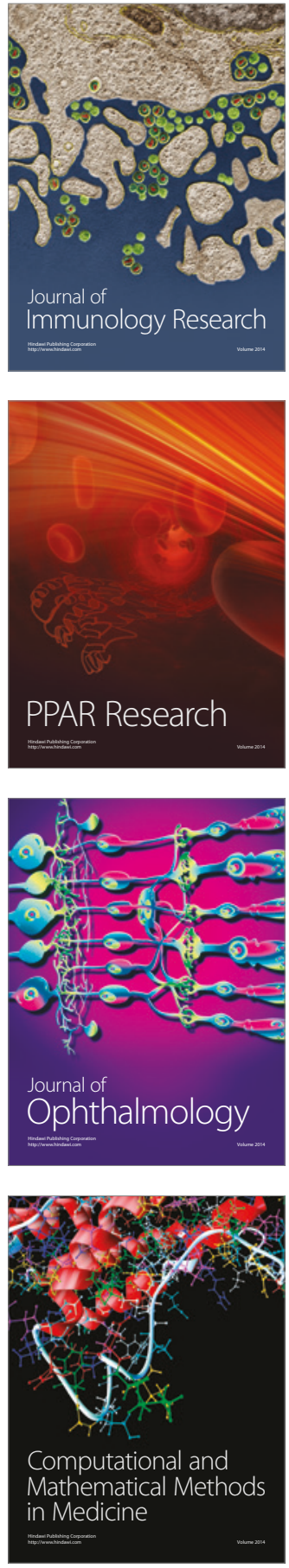

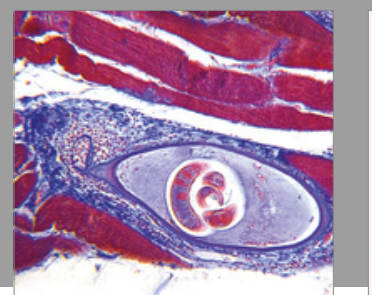

Gastroenterology Research and Practice
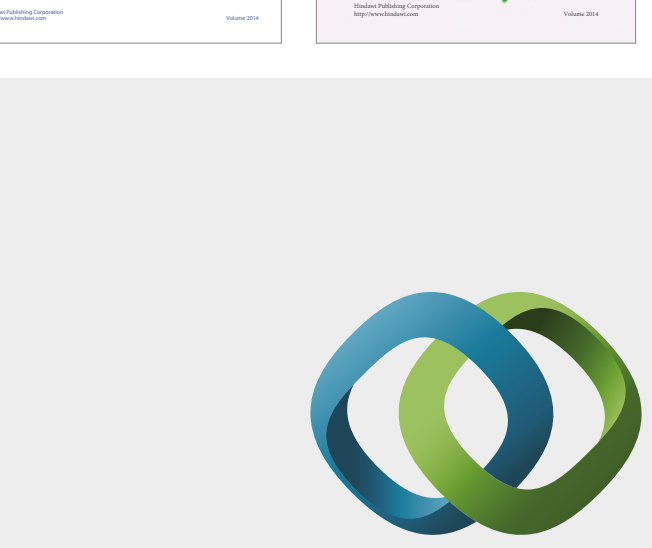

\section{Hindawi}

Submit your manuscripts at

https://www.hindawi.com
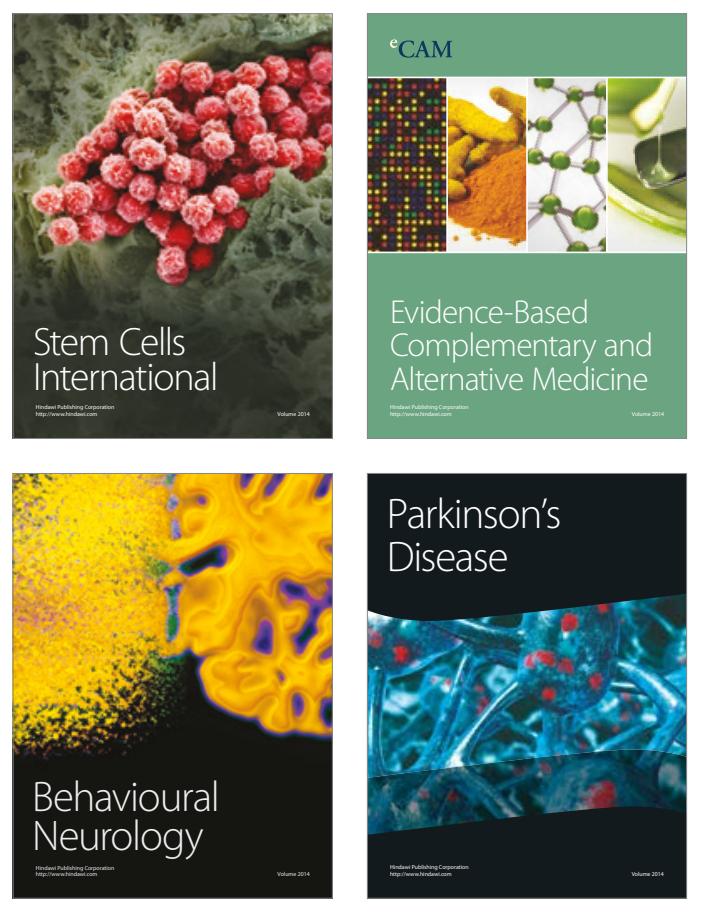
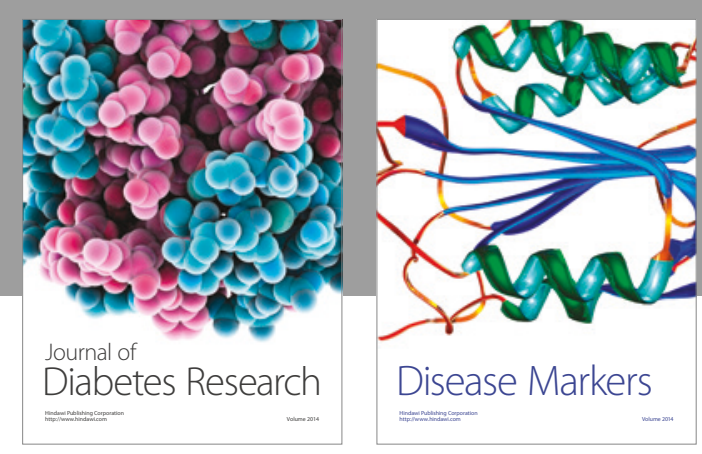

Disease Markers
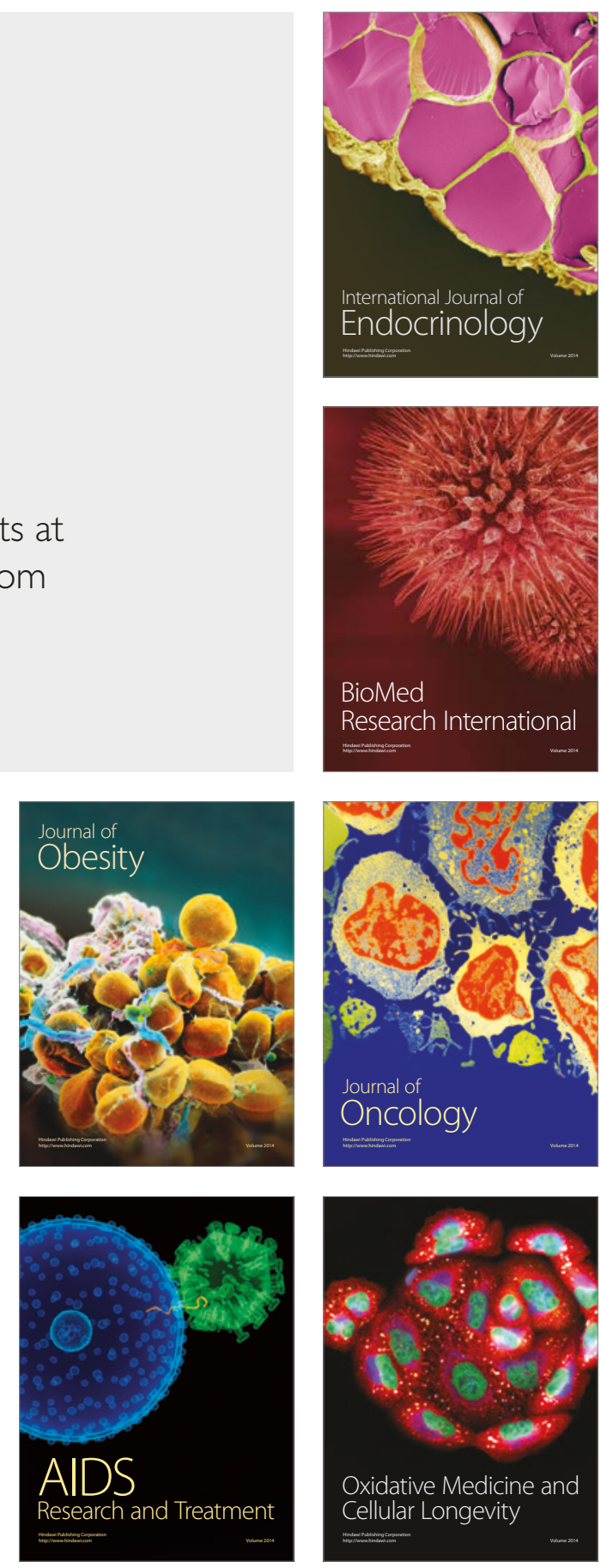